\title{
Developing of Fuzzy Learning Module for Undergraduate Student
}

\author{
Hakkun Elmunsyah $^{1}$, Dyah Rosita Anggraeni ${ }^{2}$, Anik Nur Handayani ${ }^{3}$ \\ 1,2,3 Department of Electrical Engineering, State University of Malang, Indonesia \\ hakkun@um.ac.id,dyahrosita00@gmail.com, handayani.aniknur@gmail.com
}

\begin{abstract}
This study aimed to produce and knowing the feasibility of fuzzy learning module for undergraduate students. At this development research, it is implemented at electrical engineering education program of Electrical Engineering Department, Universitas Negeri Malang. We used ADDIE to develop the module with five development stages, consist of: (1) analysis, (2) design, (3) development, (4) implementation, and (5) evaluation. As the result of the study, fuzzy learning module will be validated by content and media experts also tested on students who had taken the Intelligent System subject using quistionnare. Overall results of this study indicate that fuzzy learning module proper to use.
\end{abstract}

Keywords-Development; Learning Module; Fuzzy Logic; Intelligent System

\section{INTRODUCTION}

Fuzzy logic theory had been widely applied in various fields of work, including on equipment and machinery supporting human work. This application is manifested in the use of the controller principle of industrial tools and machinery. By using fuzzy logic, efficiency and effectiveness of work completion can be achieved. In addition, there will be various benefits and performance to improve the existing controller system. As a controller, fuzzy system will provide more precise results in accordance with the given set point, compared with a convensional that only controls an equipment with "on" or "off"[5]. Fuzzy logic is one component of several types of problem-solving techniques in artificial intelligence called soft computing formers. The value of truth in fuzzy logic expressed by the degree of membership, which a value can be true or false at the same time [7]. The usefulness of fuzzy theory in the world of work can be realized very quickly by research and development strategies that explore by the industry. However, it is also followed by the need of engineers who are familiar with fuzzy control theory. These problems, can be solved through field of education by increasing procurement of books and writing of scientific works with fuzzy as a subjects in every college or other educational institutions.

Based on Catalog of Electrical Engineering Department, Universitas Negeri Malang in 2014, there are Intelligent System as compulsory subject for students of Electrical Engineering Education with concentration of instrumentation and control. In this subject, students must be understand about the materials and apply it in the field of electronics. One of the competency are discussed is Fuzzy Logic. It can be a solution to increase knowledge and application of fuzzy logic for students who will work in industry. However, the learning process of Intelligent System learning carried out here, there is no structured book to the app of fuzzy in accordance with the field of electrical engineering education expertise. Bahri states that the module is one of the teaching materials that have an important role in the learning process, which contains materials, methods, and evaluation to help students achieve the expected learning competence according to their own level [1]. Other than that, limited time given for fuzzy material also affects to the learning process that impact on student learning outcomes. This is due to the different time needed among student with the other to understand the material.

To solve the problem, its important to do research and development of supporting tools that can facilitate the students in studying fuzzy. Research and development methods which is implemented for of education, are used to develop and validate products used in education and learning. Developed product must be structured in accordance with the needs of Intelligent System learning in Department of Electrical Engineering, Universitas Negeri Malang. In addition, the module should be used as independent by the students both inside and outside class. There are several types of learning products that can be used to help students understand the material and improve students learning outcomes, one of them is by using learning module. This is supported by the results of research on improving student learning outcomes using modules done by Prima Putri in 2014. The results showed that students have more attention in class, submit all the tasks and get more seriously in learning than before [10].

Module is one of the learning sources which arranged systematically using language that is easily understood by students in accordance to their knowledge level and age. In addition, module must be able to be used independently to achieve the expected competencies [12]. Modules that are able to motivate students to learn and improve the quality of learning, in the module development process need to consider some characteristics, namely: self instruction, self contained, standalone, adaptive, and user friendly [9]. Based on the description, it is necessary to do research of fuzzy learning module which can be used to study independently and structured based on the needs of Electrical Engineering Education Program, Universitas Negeri Malang. 


\section{METHOD}

In this research, we choose ADDIE model with five development stages, consist of: (a) Analysis, (b) Design, (c) Development, (d) Implementation, and (e) Evaluation as shown in Fig 1. In ADDIE model, there is framework to respond the complexity of the learning environment by responding to various situations and contexts, this makes the ADDIE process remains the most effective way of product development to date. For the learning process, the concept of the ADDIE approach is based on obtaining an overall view of the learning process. It is characterized by an orderly process for gathering and analyzing collective and individual performance requirements, and the ability to respond to identified learning and training needs [3].

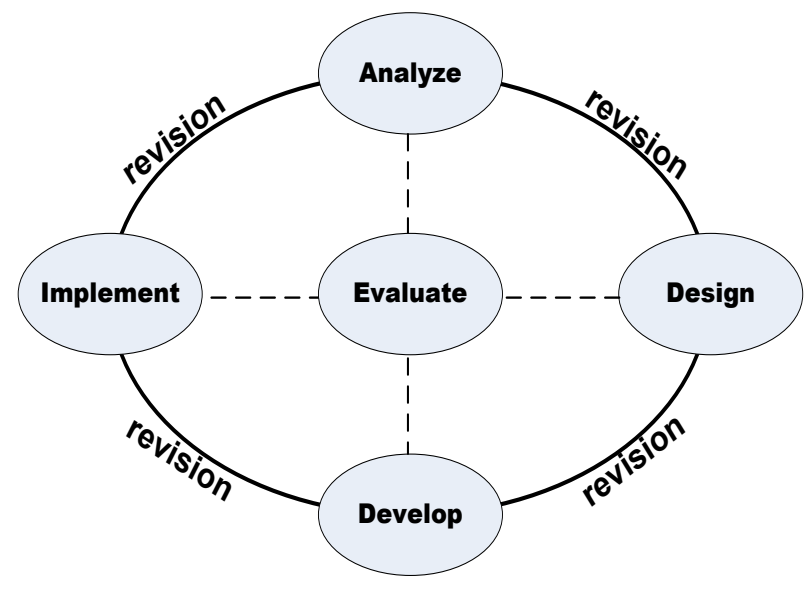

Fig. 1. Steps of ADDIE Development Model

At the analysis stage, we observed the needs of fuzzy learning modules for Intelligent Systems subject. Observation activities has done by giving questionnaire to students who had taken the subject and interview with Intelligent System lecturer. The result of the analysis activity used as basis for designing the learning module according to the Intelligent System learning needs. At the design stage, we create display and structure of the module. Meanwhile, design of research instruments will be used in the form of a questionnaire. The development stage is a follow-up activity of design stage. The conceptual design that had been made in the design stage, realized to be a product that is ready to be implemented. Evaluation at the this stage, done by validate module to the content and media experts. The result from validation used as basis for improving the developed product to be ready for implementation.

At the implementation stage, the product is tested to find out the feasibility of module. Implementation has done in two stages, small and large group trial. Small group trial conducted to four teen students who had taken subject of intelligent system. Meanwhile, large group trial conducted to thirty students who is taking the subject. The instruments used to collect data are questionnaires, with a form of checklist and assessment response based on likert scale. There are three types of questionnaires that used: (1) expert material validation, (2) expert media validation, and (3) user test. Questionnaires will be used for collect data, prepared based on assessment guidelines presented by several experts, consist of: instructional design, quality of components module, and visual communications aspects. Response assessments given by respondents are categorized into four grain scales according to those proposed by Arikunto [4] shown in Table I.

TABLE I. RESPONSE ASSESSMENT QUESTIONNAIRE

\begin{tabular}{|l|l|}
\hline Score & Information \\
\hline 1 & $\begin{array}{l}\text { Rating given very well / very complete / very appropriate / very } \\
\text { interesting / very easy to understand / and very feasible. }\end{array}$ \\
\hline 2 & $\begin{array}{l}\text { Rating given well / complete / appropriate / appropriate / } \\
\text { interesting / easy to understand / and feasible. }\end{array}$ \\
\hline 3 & $\begin{array}{l}\text { Rating given not good / less complete / less appropriate / less } \\
\text { interesting / less easy to understand / and less feasible. }\end{array}$ \\
\hline 4 & $\begin{array}{l}\text { Rating given is not good / incomplete / inappropriate / not } \\
\text { appropriate / not interesting / not easy to understand / not feasible. }\end{array}$ \\
\hline
\end{tabular}

The data which had been acquired from this research are qualitative and quantitative data. Qualitative data are comments, criticism and suggestions that given by validator and respondents. This data used as consideration in product revisions. While, the quantitative data is the percentage of value from the questionnaire given to the material experts, media experts, and students as the subjects of the trial. Quantitative data were analyzed to determine percentage of feasibility from developed module using Eq. 1.

$$
P=\frac{\sum x}{\sum x i} \mathrm{x} 100 \%
$$

\section{P: Percentage \\ $\Sigma x$ : Total score of respondents' answers $\Sigma x i$ Maximum score}

As a guidline for making a decision on data analysis result, there is a validity criterion shown in Table II [2].

TABLE II. VALIDITY CRITERION

\begin{tabular}{|l|l|}
\hline Percentage & Information \\
\hline $85.01 \%-100 \%$ & Very valid, can be used without revision. \\
\hline $70.01 \%-85.00 \%$ & Quite valid, can be used with a small revision. \\
\hline $50.01 \%-70.00 \%$ & $\begin{array}{l}\text { Less valid, it is recommended not to be used } \\
\text { because it needs major revision. }\end{array}$ \\
\hline $1.00 \%-50.00 \%$ & Invalid, or may not be used. \\
\hline
\end{tabular}

\section{RESULT}

The result of this research is Fuzzy learning module. Developed module consist of two types are lecturer module and student module. Structure of developed module consist of cover, foreword, module position map, glossary, introduction, learning, evaluation, and answer key for the lecturer's module.

Introductory of module contains of introductory words, table of contents, table lists, list of images, and list of equations to help users find information easier from the module. Module equipped with a modular map that showing fuzzy module position among other Intelligent System modules. In addition, glossary containing explanations of difficult words relating to fuzzy material. Introduction module provides details information of module usage, consisting of competency standards, module description, prerequisites, 
instructions of module usage, goals, and indicators of competency. Learning section of the module contains the description of the material served in the form of learning activities. There are five learning activities, consist of: (1) fuzzy logic and set, (2) fuzzy membership function, (3) fuzzy inference engine, (4) defuzzification, and (5) fuzzy application using labVIEW. Each learning activity consist of: (1) goals, (2) material description, (3) summary, (4) evaluation of learning activities, and (5) references. Evaluation sections of the module consist of theoretical and skill competency tests and the criteria of assessment. Lecturers module completed with rubric of assessment and answers key.

Validation of content module done by lecturer of Electrical Engineering. Comments and suggestions obtained from expert can be seen in Table III.

TABLE III. COMMENT AND ADVICE FROM MATERIAL EXPERT

\begin{tabular}{|l|l|}
\hline $\begin{array}{l}\text { Component of } \\
\text { Module }\end{array}$ & Comment and Advice \\
\hline $\begin{array}{l}\text { Learning } \\
\text { Objectives }\end{array}$ & $\begin{array}{l}\text { Verbs that used in learning objectives need to be matched } \\
\text { with Bloom taxonomy. }\end{array}$ \\
\hline $\begin{array}{l}\text { Example and } \\
\text { Evaluation }\end{array}$ & $\begin{array}{l}\text { The example does not describe the detail of fuzzy problem } \\
\text { which is being discussed, its need to add explanation about } \\
\text { the detail of the role of fuzzy system as control in the } \\
\text { example and the evaluation questions provided. }\end{array}$ \\
\hline Cover & $\begin{array}{l}\text { Background color used in cover module is too dark, its } \\
\text { necessary to select lighter color and add some image } \\
\text { supporters of fuzzy system. }\end{array}$ \\
\hline Answer Key & $\begin{array}{l}\text { Add a page on each of the question which is being } \\
\text { discussed. }\end{array}$ \\
\hline
\end{tabular}

The result of validation summarized by each indicator presented in Table IV.

TABLE IV. RESULT OF MATERIAL EXPERT VALIDATION

\begin{tabular}{|l|l|l|l|l|}
\hline \multirow{2}{*}{ Indicator } & \multicolumn{3}{|l|}{ Student Module } & \multicolumn{2}{l|}{ Lecturer Module } \\
\cline { 2 - 5 } & Perc & Inf. & Perc. & Inf. \\
\hline Clarity and relevance & $100 \%$ & Very Valid & $93.75 \%$ & Very Valid \\
\hline Accuracy & $91.67 \%$ & Very Valid & $87.5 \%$ & Very Valid \\
\hline Depth and ease of material & $100 \%$ & Very Valid & $100 \%$ & Very Valid \\
\hline Completeness and quality & $81.25 \%$ & QuiteValid & $93.75 \%$ & Very Valid \\
\hline Systematic, traceable & $100 \%$ & Very Valid & $91.67 \%$ & Very Valid \\
\hline Consistency & $75 \%$ & QuiteValid & $83.33 \%$ & QuiteValid \\
\hline Visual & $75 \%$ & QuiteValid & $87.5 \%$ & Very Valid \\
\hline Simple and alluring & $100 \%$ & Very Valid & $100 \%$ & Very Valid \\
\hline Communicative & $100 \%$ & Very Valid & $100 \%$ & Very Valid \\
\hline Average & $91.44 \%$ & Very Valid & $93.05 \%$ & Very Valid \\
\hline
\end{tabular}

Based on the result of analysis data, there are average precentage of the overall result $91.44 \%$ for the student module and $93.05 \%$ for the lecturer module. In accordance with the criteria of validation on the Table II. then both the result are included in category of very valid.

Process of media validation done by expert on learning media, while the comment and advice can be seen in Table V.
TABLE V. COMMENT AND ADVICE FROM MEDIA EXPERT

\begin{tabular}{|l|l|}
\hline $\begin{array}{l}\text { Component of } \\
\text { Module }\end{array}$ & Comment and Advice \\
\hline $\begin{array}{l}\text { Skill } \\
\text { Kompetency Test }\end{array}$ & $\begin{array}{l}\text { Add a report form in accordance with rating rubric that } \\
\text { had been created. }\end{array}$ \\
\hline $\begin{array}{l}\text { Numbering of } \\
\text { Module Chapter }\end{array}$ & $\begin{array}{l}\text { Numbering used of the sub chapter still dificult to } \\
\text { separate with the content of module. Fix the numbering } \\
\text { as not mixed with the material presented. }\end{array}$ \\
\hline Table & $\begin{array}{l}\text { Table color used is too dark. Improve the color with the } \\
\text { brighter one so the information of the table become } \\
\text { easier to read. }\end{array}$ \\
\hline
\end{tabular}

The result of validation summarized by each indicator presented in Table VI. All of indicator included in the category of very valid with average percentage $97.70 \%$.

TABLE VI. RESULT OF MEDIA EXPERT VALIDATION

\begin{tabular}{|l|l|l|}
\hline Indicator & Percentage & Information. \\
\hline Relevance & $100 \%$ & Very Valid \\
\hline Completed presentation & $100 \%$ & Very Valid \\
\hline Easy to understand & $100 \%$ & Very Valid \\
\hline Systematic writing & $100 \%$ & Very Valid \\
\hline Consistency & $91.67 \%$ & Very Valid \\
\hline Color and layout design & $90 \%$ & Very Valid \\
\hline Typography & $100 \%$ & Very Valid \\
\hline Communicative & $100 \%$ & Very Valid \\
\hline Average & $97.70 \%$ & Very Valid \\
\hline
\end{tabular}

According with the result of validation experts, revised module will tested on small group trial. This process had done by four teen students who had taken Intelligent System subject. We use random sampling tehnique to get the sample ad the result presented in Tabel VII.

TABLE VII. RESULT OF SMALL GROUP TRIALS

\begin{tabular}{|l|l|l|}
\hline \multirow{2}{*}{ Indicator } & Small Group \\
\cline { 2 - 3 } & Perc & Inf. \\
\hline Clarity and relevance & $97.32 \%$ & Very Valid \\
\hline Accuracy & $93.45 \%$ & Very Valid \\
\hline Depth and ease of material & $90.18 \%$ & Very Valid \\
\hline Completeness and quality & $99.11 \%$ & Very Valid \\
\hline Systematic writing & $92.86 \%$ & Very Valid \\
\hline Color and layout design & $86.78 \%$ & Very Valid \\
\hline Typography & $94.04 \%$ & Very Valid \\
\hline Communicative & $95.09 \%$ & Very Valid \\
\hline Average & $93.60 \%$ & Very Valid \\
\hline
\end{tabular}

The result obtained from trial analysis is $93.60 \%$ which is included in category of very valid and can be used in large group trial. Large group trial had done by thirty students who were taking the Intelligent System subject. Based on analysis result, average percentage acquired is $89.54 \%$, so it can be concluded that developed modules in category of very valid and feasible to applied in learning process. Details of the data presented in Table VIII. 
TABLE VIII. RESULT OF LARGE GROUP TRIALS

\begin{tabular}{|l|l|l|}
\hline \multirow{2}{*}{ Indicator } & Small Group \\
\cline { 2 - 3 } & Perc & Inf. \\
\hline Clarity and relevance & $96.25 \%$ & Very Valid \\
\hline Accuracy & $90 \%$ & Very Valid \\
\hline Depth and ease of material & $86.25 \%$ & Very Valid \\
\hline Completeness and quality & $96.87 \%$ & Very Valid \\
\hline Systematic writing & $87.08 \%$ & Very Valid \\
\hline Color and layout design & $85.50 \%$ & Very Valid \\
\hline Typography & $85.28 \%$ & Very Valid \\
\hline Communicative & $89.17 \%$ & Very Valid \\
\hline Average & $89.54 \%$ & Very Valid \\
\hline
\end{tabular}

\section{DISCUSSION}

This research produce fuzzy learning module for lecturer and students of Electrical Engineering Education, Universitas Negeri Malang. The module be categorized as valid and feasible product after validated by the experts and tested on students. Based on the result of expert material validation, obtained the percentage of feasibility $91.44 \%$ for student module and $93.05 \%$ for lecturer module. Details of the result presented on the graph shown in Figure 2.

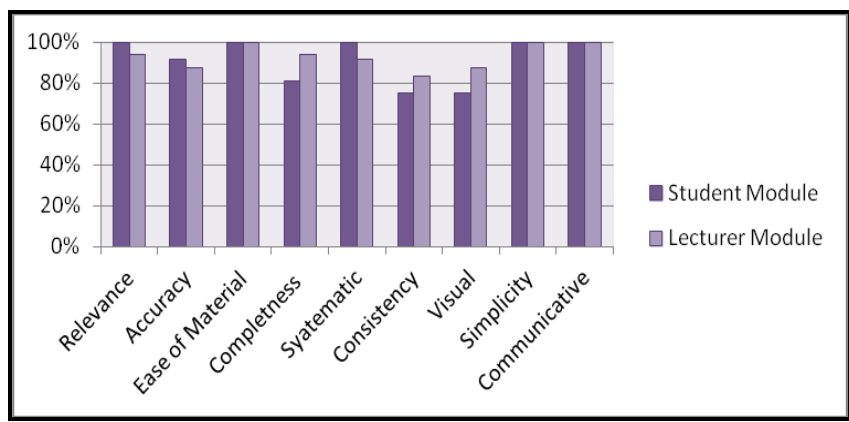

Fig. 2. The Graph of Material Expert Data

The developed module present some learning objectives relevant to competency standards should be mastered by students. The material of fuzzy served in structural and spesific of learning activities form, so that allows the users to use the module easily. In addition, module equipped with some fuzzy image supporter presented as simple and use easy language that easy to understand so its support to be used in learning process. Base on the characteristics that have been described, it can be seen that developed module can be used independently (self instructional). To fulfill the characteristics of self instruction, a module must be used independently, equipped with clear and systematic learning objectives that describe the competency should be mastered by students, using communicative language, examples and illustrations that can help students in understanding the material [11].

The result of media expert validation show that the modul feasible to use with average percentage is $97.70 \%$. Details of data presented on the graph shown in Figure 3.

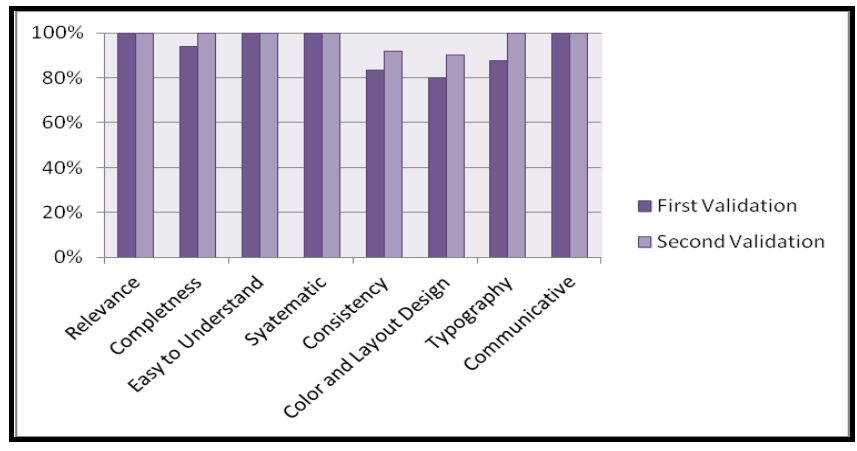

Fig. 3. The Graph of Media Expert Data

The developed module consist of introductory, learning, and references used in the preparation of module, so that students can learn independently and explore more knowledge about fuzzy by accessing these references. The material served complete in the form of five learning activities as follows: 1) introduction of fuzzy logic, 2) degree of membership function fuzzy, 3) fuzzy inference, 4) defuzzification, and 5) applications of fuzzy in electronics using LabVIEW. The examples presented as supporter in the module which is adapted to the field of student expertise in electronics. In accordance with the components of module has developed, it can be seen that the module is self contained because it contains all the required learning materials and has a reference that can be used to increase knowledge about fuzzy. A module is said to be self contained if it provides clear guidance of material and some supporting information that should be studied [2].

In addition the module is adaptive by displaying contextual examples of fuzzy material that makes module more interesting and easy to understand. According to Mahfudhillah, the use of materials or contextual modules is an important factor in determining the quality of learning. Its can help the students to relate the material learned with the reallife context [8]. After through the validation by experts, module tested on the students. Details of the trial results are presented on the graph shown in Figure 4.

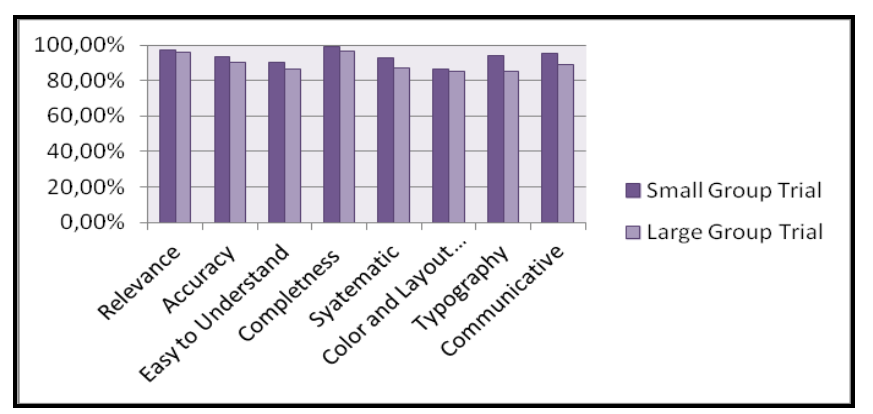

Fig. 4. The Graph of Small and Large Group Data

Based on the analysis data, it is known that the percentage obtained in small group trial is higher than large group trial. It it is caused by the respondents in small group are students who have studied fuzzy logic materials. So the understanding of fuzzy material more than the respondents in large group trials that just get the material. The whole aspects of the trials was in 
category of very valid. The module served with communicative language and terms that makes module easy to understand. From the characteristics of the developed module, it can be concluded that the module was user friendly. This is in accordance with what Widyawati states, the language used in the module should use terms or vocabularies that are easily understood by the students [12].

The results of responses from these users strongly support the results of Elmunsyah's research that improving the effectiveness of learning can be achieved through three efficiency measures: interaction, understanding and absorption. Here, it is expected that there will be an increase in the effectiveness and interaction between lecturers and students so that the learning objectives can be achieved [4]. The overall exposure of this research is expected with the fuzzy module is expected to have a close relationship between vocational maturity with the development and maturity in the skill domain. As Hariningtyas, et al declare that one who seeks to explore oneself and self-evaluate whose purpose in the development of his abilities can be said to have vocational maturity [6].

\section{CONCLUSION}

The results of the research are fuzzy learning modules for lecturer and student. Based on the result of validation and trial process, it can be concluded that the developed module is feasible to applied on intelligent system subject in Electrical Engineering Department, Universitas Negeri Malang. For further development, it is expected that there will be more varied inference models and defuzzification methods in accordance to technological developments.

\section{REFERENCES}

[1] Bahri, Samsul., Syamsuri, Susriyati. 2016. Pengembangan Modul Keanekaragaman Hayati dan Virus Berbasis Model Inkuiri Terbimbing untuk Siswa Kelas X Man 1 Malang Vol. 1, No. 2 (Online), (http://journal.um.ac.id/), accessed 6 Juni 2017.

[2] Chao, L.2014. Cloud Database Development and Management. Florida, USA: CRC Press, Taylor \& Fancis Group.

[3] Clark, D.R. 2015. Why Instructional System Design and ADDIE?. (Online), (http://www.nwlink.com/ donclark/hrd/sat1.html), accessed 16 Juni 2017.

[4] Elmunsyah, H. 2014. A National Education Policy-Based ICT Model for Indonesian High Schools (VHS). Global Journal of Engineering Education Vol. 16, No. 3 (Online), (http://www.wiete.com.au/journals/ GJEE/Publish/vol16no3/06-Elmunsyah-H.pdf), accessed 26 Juni 2017.

[5] Febiyanti A., Rahmat, Wibowo. 2016. Implementation of PID and Fuzzy Logic Control to DC Motor Speed Control System as Digital Control Practicum Application Vol. 3, No. 3 (Online),

[6] (http://openlibrary.telkomuniversity.ac.id/), accessed 16 Juni 2017.

[7] Hartiningtyas Lativa, Purnomo, Elmunsyah, H. 2016. Hubungan Antara Self Regulated Learning dan Locus of Control Internal dengan Kematangan okasi Siswa SMK Vol 1, No. 6 (Online), (http://journal.um.ac.id/), accessed 15 Juni 2017.

[8] Kusumadewi, Sri, dan Hari Purnomo. 2014. Aplikasi Logika Fuzzy untuk Pendukung Keputusan Edisi 2. Yogyakarta: Graha Ilmu.

[9] Mahfudhillah, Hamim T., Mimien Henie, Sueb. 2017. Pengembangan Modul Kawasan Rumah Pangan Lestari (KRPL) Berbasis Proyek untuk Siswa SMA Vol. 2, No. 3 (Online),

[10] (http://journal.um.ac.id/), accessed 29 Juni 2017.

[11] Nurdiansah, Dimas., Tiwan. 2017. Autocad Module Development For Mechanical Engineering Students At Muhammaduyah 1 Salam Vhs Vol.5, No. 1, (Online), (http://journal.student.uny.ac.id/), accessed 16 Juni 2017.

[12] Putri, Prima. 2014. Upaya Meningkatkan Hasil Belajar MahasiswaTeknik Sipil FT UNP Pada Mata Kuliah Analisis Struktur Dengan Menggunakan Modul. Prosiding Konvensi Nasional APTEKINDO VII, 374-579, (Online),

[13] (http://jurnal.upi.edu/proceedingfptk/edition/437), accessed 13 Juni 2017.

[14] Sunantri, Asep., Suyatna, Rosidin. 2016. Pengembangan Modul Pembelajaran Menggunakan Learning Content Development System Materi Usaha Dan Energi Vol.4 No 1, (Online), (http://jurnal.fkip.unila.ac.id/), accessed 17 Juni 2017.

[15] Widyawati. 2016. Pengembangan Modul Pembelajaran pada Mata Pelajaran Teknik Instalasi Listrik di SMK PGRI 1 Lamongan Vol.5, No. 2, (Online), (http://jurnalmahasiswa.unesa.ac.id/), accessed $16 \mathrm{Juni}$ 2017. 